\title{
Prosthetic Laboratory Influence on the Vertical Misfit at the Implant/UCLA Abutment Interface
}

\author{
Gustavo Augusto Seabra BARBOSA ${ }^{1}$ \\ Paulo Cézar SIMAMOTO JÚNIOR ${ }^{2}$ \\ Alfredo Júlio FERNANDES NETO ${ }^{3}$ \\ Maria da Glória Chiarello de MATTOS ${ }^{4}$ \\ Flávio Domingues das NEVES ${ }^{3}$
}

\author{
${ }^{1}$ Department of Dentistry, Federal University of Rio Grande do Norte, Natal, RN, Brazil \\ ${ }^{2}$ Department of Prosthodontics, School of Dentistry of Piracicaba, State University of Campinas, Piracicaba, SP, Brazil \\ ${ }^{3}$ Department of Fixed Prosthodontics, Occlusion and Dental Materials, School of Dentistry, \\ Federal University of Uberlândia, Uberlândia, MG, Brazil \\ ${ }^{4}$ Department of Dental Materials and Prosthodontics, School of Dentistry of Ribeirão Preto, \\ University of São Paulo, Ribeirão Preto, SP, Brazil
}

\begin{abstract}
An inadequate fit at the abutment/implant interface can generate mechanical and biological problems. The laboratorial stages could induce misfit in such interface when the castable UCLA abutment type is used. The purpose of this study was to comparatively evaluate the performance of three prosthetic laboratories (Labs A, B and C) by vertical fit analysis of castable UCLA abutments on the casting and soldering stages of the same prosthesis. Four fixed prostheses were built by each laboratory using castable UCLA abutments. The evaluation was made by scanning electron microscopy under 500x magnification in the mesial and distal regions of each element of the prosthesis, totalizing 24 measurements per laboratory. The results were analyzed statistically by Kruskal-Wallis test $(p<0.05)$. In the casting process, the values presented by the laboratories differed significantly to each other $(p=0.004)$. After soldering, the values presented by the laboratories showed no significant difference $(p=0.948)$. It may be concluded that the fit values obtained in the casting stage of UCLA abutments can be influenced when processed by different laboratories, and that conventional soldering itself increased the degree of framework misfit, regardless of which laboratory made it.
\end{abstract}

Key Words: dental implants, implant-supported dentures, denture fitting.

\section{INTRODUCTION}

The UCLA abutment was developed at the University of California, USA, in the 1980's. It is a castable plastic cylinder that directly connects to the implant and also can be modified by the laboratory technician by means of steps like waxing, casting and porcelain building $(1,2)$. The low cost, capability to overcome problems such as limited interocclusal distance and small interproximal distance between implants, as well as the possibility of implant angulations error counterbalance, are also pointed out as advantages of this abutment (1-4). A great disadvantage of UCLA abutment is its abutment/implant fit because the laboratorial steps might cause a misfit, which may result on screw loosening and/or fracture as well as implant loss and/or fracture (5-8).

The abutment/implant interface has been reported as a significant factor on stress transfer, adverse biological responses or prosthetic reconstruction complications. Several factors related to implant component manufacturing, as well as the clinical and laboratorial steps effect can contribute to a clinical misfit of the prosthesis $(9,10)$. Laboratorial steps, such as casting, soldering and porcelain building, or the combination of them, can result in distortion during prosthesis manufacturing, when UCLAabutments are used (11-13).

Two types of possible complications to a pros-

Correspondence: Prof. Gustavo Augusto Seabra Barbosa, Avenida dos Potiguares, 2323, Bl. 4; Apt. 504, Lagoa Nova, 59063-450 Natal, RN, Brasil. Tel: +55-84-3231-1762. e-mail: seabrabarbosa@uol.com.br/gustavoseabra@ufrnet.br 
thesis framework misfit can occur: a) biological increase of load transfer to bone, bone loss and bacterial growth at the microgap between the abutment and the implant (13-15); and b) prosthetic - screw loosening or fracture and implant loss (13).

Pre-machined abutments, including those that underwent overcasting and porcelain building, have a better fit than castable abutments $(11,16,17)$. Some studies $(18,19)$ have shown that when castable UCLA abutments are used, vertical misfit greater than $10 \mathrm{~mm}$ are present at every laboratorial stages, which may pose a risk to the use of these abutments that is exacerbated by the soldering process.

Considering the importance of the laboratorial steps on the UCLA abutment/implant fit, the purposes of this study were to evaluate comparatively by scanning electronic microscopy the vertical adjustment of castable UCLA type abutment, after casting and soldering stages of the same prosthesis, and to verify the influence of three different dental prosthetic laboratories on these processes.

\section{MATERIAL AND METHODS}

Two metal matrices were inserted in a master cast, simulating 3 tooth absences in each hemiarch: 2 nd premolar, 1st molar and 2nd molar. The matrixes measured 27.6 X $18.8 \times 12.7 \mathrm{~mm}$ and each one had 3 Bränemark-compatible implants $(10 \times 3.75 \mathrm{~mm})$ with regular platform inside it $(4.1 \mathrm{~mm}$; Conexão Sistemas de Prótese LTDA,São Paulo, SP, Brazil) (Fig. 1). Waxing of the peri-implant gingival area was made with sticky wax (Horus; Herpo, Rio de Janeiro, RJ, Brazil) in order to mimic the gingival tissues. Impressions were made using an open custom-made tray and regular set polyether impression material (Impregum F 3M/ESPE, St. Paul, MN, USA). All steps were performed in both arches of the master cast, but due to practical reasons only the procedures of the maxillary arch are hereby stated. Plaster models obtained with type IV gypsum (Durone, Dentsply Ind. e Com. Ltda., Petrópolis, RJ, Brazil) were sent to 3 prosthetic laboratories (A, B and C) for fabrications of the prostheses.

Each laboratory constructed four 3-unit fixed denture frameworks: 1 upper right, 1 upper left (Fig. 2), 1 lower right and 1 lower left, casting in nickelchromium alloy (Verabond II; Aalba Dent Inc., Cordelia, CA, USA).
After casting, the frameworks were placed over the metal matrix, beginning with hand tightening, followed by a $20 \mathrm{Ncm}$ torque, with a screwdriver hand torque meter (Conexão Sistemas de Prótese LTDA). Thereafter, the frameworks were examined with a scanning electron microscope (LEO VP 435, Carl-Zeiss NTS GmbH, Oberkochen, Germany) at X500 magnification for the first abutment/implant interface observation (post-casting examination). After the first scanning electron microscopic evaluation, the frameworks were bonded for solder (conventional solder) and then were forwarded to the respective labs. After soldering, the framework abutment/ implant interfaces were re-examined following the same procedure previously described (Fig. 3).

For each framework abutment, two images were obtained, a mesial and a distal, totalizing 24 images, which were laser printed (Laser Jet 1500L, HewlettPackard, USA). With the printed photos, a ruler was obtained from the micrometer scale on images lower portion.

If there was any vertical fit/misfit, a line was traced parallel to the implant platform surface and another parallel to the bottom surface of the abutment. After this, the distance between both surfaces was measured (Fig. 4). Aiming a better result view, numbers were given to the measurement sites, region 1 being mesial of the upper right premolar, region 2 being distal of the upper right premolar and so on, following the sequence: upper right, upper left, lower right and lower left prostheses, initiating of mesial premolar to distal 2nd molar region. Factors that could interfere with the accurate determination of a possible adjustment, namely visual accuracy, view angle, light and professional expertise were described (19). In order to minimize the interference of such factors, 3 calibrated examiners made the measurements. Data were analyzed statistically by Kruskal Wallis and Mann-Whitney tests using the statistical software package SPSS for Windows (SPSS Inc., Chicago, IL, USA). Non-parametrical tests were chosen due to the non-normal sample distribution of the data of Lab B and to the independent nature of the data of all three Labs. Statistical significance level was set at $5 \%$.

\section{RESULTS AND DISCUSSION}

Table 1 presents the results of vertical fit/misfit of the 3 Labs evaluated in this study after casting and 
soldering.

Regarding casting, the results showed statistically significant difference among the groups $(p=0.004)$. There was significant difference between Lab A and Lab $B$ values $(\mathrm{p}=0.001)$. Student's t-test showed difference between Lab A and Lab C ( $p=0.032)$, but no significant difference was found between Lab B and Lab C by the Mann-Whitney test $(\mathrm{p}=0.160)$, Lab A presenting significantly lower values than Labs B and C.

Although there are no specific data related to what is considered clinically acceptable to misfit levels (9), in the present study, a misfit level equal to or lower than $10 \mathrm{~mm}$ was considered as acceptable, according to previous information about osseointegration (20).

Analysis of relative accumulated frequency ( $\mathrm{Fr}$ )

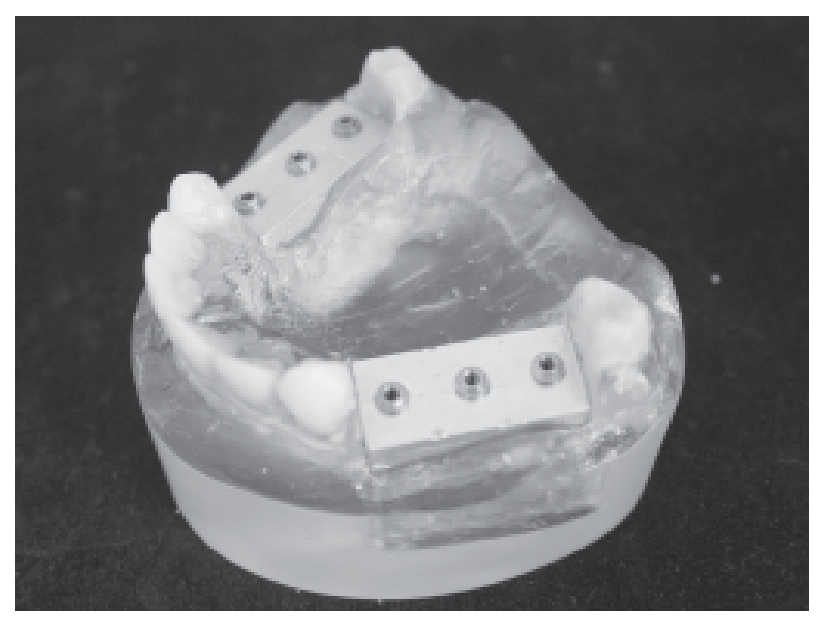

Figure 1. Metal matrix in upper master cast.

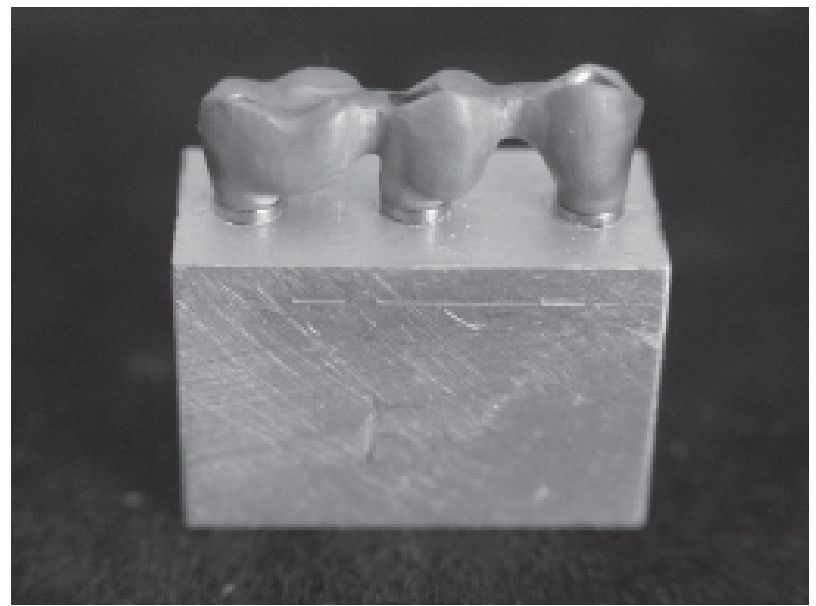

Figure 3. Frameworks placed on metal matrix for SEM analysis. showed a fit/misfit ratio equal to or lower than $10 \mu \mathrm{m}$. Multiplying "Fr" values by hundred, we can obtain a percentage frequency.

Lab A presented significantly lower values than Labs $B(p=0.001)$ and $C(p=0.032)$, ranging from 0 to $11.6 \mathrm{~mm}$, with $95.8 \%$ of their values between 0 and 10 $\mathrm{mm}$. Lab C values ranged from 0 and $13.3 \mathrm{~mm}$, with $87.5 \%$ of its values between 0 to $10 \mathrm{~mm}$. Lab B values ranged from 0 to $51.7 \mathrm{~mm}$, with only $70.8 \%$ of its values being close to $10 \mathrm{~mm}$. Although Labs B and C values did not differ significantly to each other $(\mathrm{p}=0.160)$, such a difference can be clinically relevant because the highest value of Lab C was $13.3 \mathrm{~mm}$.

Regarding solder analysis, there was no statistically significant difference between the three Labs

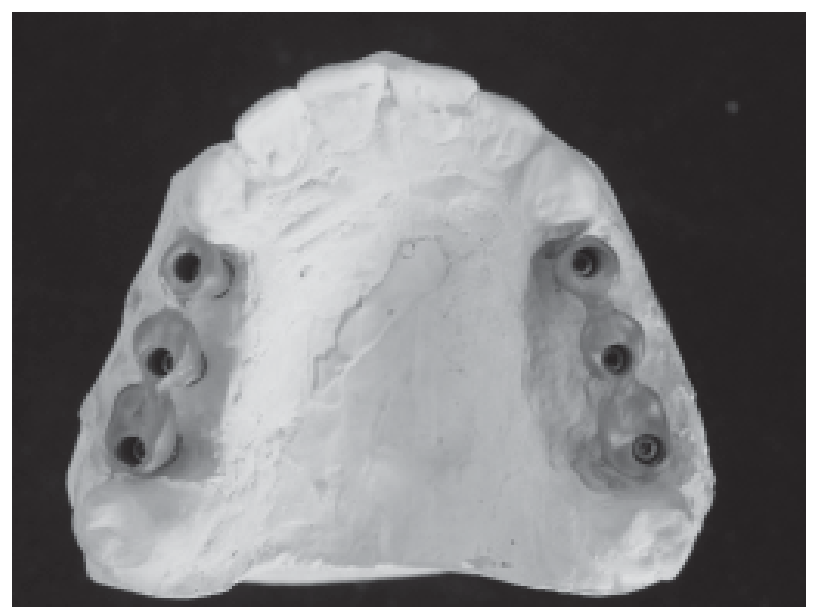

Figure 2. Frameworks machined by the labs (four per lab).

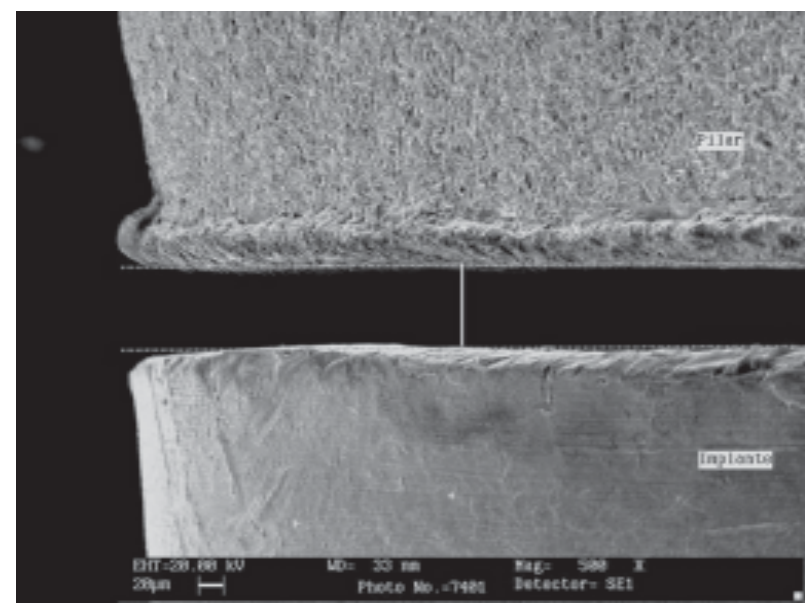

Figure 4. Demonstration of vertical fit/misfit analysis. 
$(\mathrm{p}=0.948)$, Labs A and B presenting $70.8 \%$ of their values around $10 \mathrm{~mm}$. For Lab C, 79.1\% of the values were around this average.

The abutment/implant interface has been re-

Table 1. Examiners average $(\mu \mathrm{m})$ for vertical fit $/$ misfit after casting and soldering.

\begin{tabular}{lll}
\hline Region $\quad$ Casting & Soldering \\
\hline
\end{tabular}

Lab. A Lab. B Lab. C

Lab. A Lab. B Lab. C

\begin{tabular}{ccccccc}
\hline 1 & 0 & 21.6 & 7.5 & 16.6 & 0 & 5 \\
2 & 5 & 12.5 & 10 & 33.3 & 16.7 & 15 \\
3 & 11.6 & 5 & 7.5 & 5.8 & 17.5 & 2.5 \\
4 & 5 & 10 & 12.5 & 5 & 25 & 12.5 \\
5 & 0 & 5 & 5 & 2.5 & 5 & 21.7 \\
6 & 0 & 0.8 & 5 & 9.1 & 0 & 2.5 \\
7 & 0 & 10 & 10 & 5 & 5 & 21.7 \\
8 & 0 & 1.6 & 0 & 0 & 0 & 0 \\
9 & 0 & 0 & 0 & 1.6 & 0.8 & 0 \\
10 & 0 & 0 & 0.8 & 0 & 0 & 5 \\
11 & 7.5 & 11.6 & 10 & 5 & 0 & 0 \\
12 & 0 & 13.3 & 5.8 & 28.3 & 10 & 10 \\
13 & 2.5 & 5 & 9.1 & 30 & 22.5 & 25 \\
14 & 0 & 0 & 1.6 & 0 & 0 & 0 \\
15 & 5 & 10.8 & 5.8 & 0 & 9.1 & 2.5 \\
16 & 5 & 10 & 10 & 0 & 30 & 0.8 \\
17 & 5 & 7.5 & 0 & 0 & 0 & 0 \\
18 & 10 & 10 & 13.3 & 0 & 20 & 8.3 \\
19 & 5 & 1.6 & 12.5 & 27.5 & 0 & 2.5 \\
20 & 2.5 & 23.3 & 1.6 & 25 & 2.5 & 1.7 \\
21 & 0.8 & 54.1 & 0 & 0 & 51.7 & 0 \\
22 & 0 & 0 & 0 & 0 & 5 & 5.8 \\
23 & 0 & 10 & 0.8 & 23.3 & 10 & 5.8 \\
24 & 0 & 8.3 & 0 & 0 & 0 & 0 \\
\hline
\end{tabular}

Table 2. Percentage of vertical fit/misfit values.

\begin{tabular}{lcc}
\hline Laboratories & \multicolumn{2}{c}{ Percentage of values $<10 \mu \mathrm{m}$} \\
\cline { 2 - 3 } & Casting & Soldering \\
\hline A & & \\
B & $95.8 \%$ & $70.8 \%$ \\
C & $70.8 \%$ & $70.8 \%$ \\
\hline
\end{tabular}

ported as a significant factor on stress transfer, biological responses and final results of a prosthetic rehabilitation (9). Thus, inaccurate fit at such interface must be overcome still during provisional stage. Lack of an accurate abutment/implant interface will tend to produce biological $(5,13,14)$ and mechanical problems $(5,8,13)$.

Several studies have reported that pre-machined UCLA abutment provide a better fitting to the implant platform compared to castable UCLAabutments $(11,16-$ 18). However, this study reached better results, on both casting and solder laboratorial stages, than that found in a previous study (17), which used unpolished and unfinished pre-machined UCLA abutments. This contradicts Byrne (11), who stated that castable abutments, even using the best laboratorial techniques, do not have the same adjustment as that of premachined abutments. Within the limitations of this study, it can be stated that the use of castable UCLA type abutments and laboratories can produce results equal to or superior than those found on overcast pre-machined abutments, when there are not correctly processed. Naturally, it should not be forgotten that titanium machined abutments presents even better results (11).

Table 2 shows more satisfactory results than those of previous studies using the same abutments $(17,18)$. Elias $(17)$ observed $33.4 \%$ of the values $<10$ $\mathrm{mm}$ after casting and $27.8 \%$ after soldering. Silveira (18) found $26.7 \%$ and $36.8 \%$ of the values $<10 \mathrm{~mm}$ after casting and soldering, respectively. However, in spite of being better than those published elsewhere, some results obtained after soldering in the present study are still above the clinically acceptable values.

This study showed that the fit values obtained in the casting stage of UCLA abutments can be influenced when processed by different laboratories due to, for example, the technician's experience, casting type, etc. Conventional soldering itself increased the degree of framework misfit, regardless of which laboratory made it. Further studies varying the framework union process (e.g.: laser soldering) with the goal of verifying changes in fit/misfit values over the abutment/implant interface.

\section{RESUMO}

Um ajuste inadequado na interface pilar/implante pode gerar problemas mecânicos e biológicos. Etapas laboratoriais podem induzir a um desajuste em tal interface quando pilares do tipo UCLA calcináveis são utilizados. Este estudo propôs-se a avaliar 
comparativamente o desempenho de três laboratórios de prótese dentária (Labs A, B e C) pela análise do ajuste vertical de pilares UCLA calcináveis durante o processo de fundição e solda de uma mesma prótese. Quatro próteses fixas foram confeccionadas por cada laboratório utilizando pilares do tipo UCLA calcinável. A avaliação foi feita em microscopia eletrônica de varredura sob aumento de $500 \mathrm{x}$ nas faces mesial e distal de cada elemento da prótese, totalizando 24 medidas por laboratório. Os resultados foram analisados estatisticamente pelo teste de Kruskal-Wallis $(p<0,05)$. Na fundição, os valores apresentados pelos laboratórios diferiram estatisticamente ( $\mathrm{p}=0,004)$. Após a análise da solda, os valores não apresentaram diferença significante entre os laboratórios $(\mathrm{p}=0,948)$. Pode-se concluir que os valores de ajuste obtidos no estágio de fundição de pilares UCLA, podem ser influenciados quando processados por diferentes laboratórios e que o processo de solda convencional, por si só, aumenta o grau de desajuste da infra-estrutura, independente do laboratório que a realizou.

\section{ACKNOWLEDGEMENTS}

The authors wish to thank Conexão Sistemas de Prótese LTDA and Professor Elliot Watanabe Kitajima from the Escola Superior de Agricultura "Luiz de Queiroz" (ESALQ) for their valuable contribution.

\section{REFERENCES}

1. Lewis SG, Beumer III J, Hornburg W, Moy P. The UCLAabutment. Int J Oral Maxillofac Implants 1988;3:183189.

2. Lewis SG. An overview of Bränemark System ${ }^{\circledR}$ restorative options. J Esthet Dent 1996;8 Suppl: 3-44.

3. Lewis SG, Avera S, Engleman M, Beumer III J. The restoration of improperly inclined osseointegrated implants. Int J Oral Maxillofac Implants 1989;4:147-152.

4. Lewis SG, Llamas D, Avera S. The UCLA abutment: a fouryear review. J Prosthet Dent 1992;67:509-515.

5. Aparicio C. A new method to routinely achieve passive fit of ceramometal prostheses over Bränemark osseointegrated implants: a two-year report. Int J Periodontics Restorative Dent 1994;14:405-419.

6. Kallus T, Bessing C. Loose gold screws frequently occur in full-arch fixed prostheses supported by osseointegrated implants after 5 years. Int $\mathrm{J}$ Oral Maxillofac Implants 1994;9:169-178

7. Hebel KS, Gajjar RC. Cement-retained versus screw-retained implant restorations: achieving optimal occlusion and esthetics in implant dentistry. J Prosthet Dent 1997;77:28-35.

8. Watanabe F, Uno I, Hata Y, Neuendorff G, Kirsch A. Analysis of stress distribution in a screw-retained implant prosthesis Int J Oral Maxillofac Implants 2000;15:209-218.

9. Jemt T, Rubenstain JE, Carlsson L, Lang BR. Measuring fit at the implant prosthodontic interface. J Prosthet Dent 1996;75:314-325.

10. Riedy SJ, Lang BR, Lang BE. Fit of implant frameworks fabricated by different techniques. J Prosthet Dent 1997;78:596-604.

11. Byrne D, Houston F, Cleary R, Claffey N. The fit of cast and premachined implant abutments. J Prosthet Dent 1998;80:184-192.

12. Carotenuto G, Palumbo M, Zarone F, Nicolais L. Characterization of the interface between prefabricated gold copings and cast dental alloy in implant restorations. Clin Oral Implants Res 1999;10:131-138.

13. Michalakis KX, Hirayama H, Garefis PD. Cement-retained versus screw-retained implant restorations: a critical review. Int J Oral Maxillofac Implants 2003;18:719-728.

14. Quirynen M, Bollen CML, Eyssen H, van Steenberghe D. Microbial penetration along the implant components of the Bränemark system ${ }^{\circledR}$. Clin Oral Implants Res 1994;5:239244.

15. Gross M, Abramovich I, Weiss EI. Microleakage at the abutment-implant interface of osseointegrated implants: a comparative study. Int J Oral Maxillofac Implants 1999;14:94100 .

16. Carvalho MCA, Bondioli IR, Costa EMV, Nishioka RS, Bottino MA, Neisser MP. Fit microscope evaluation between implant and gold UCLA abutments and Teflon UCLA, casting in titanium and nickel-chromium-titanium. In vitro study. BCI 2002;9:105-110.

17. Neves FD, Panzeri H, Fernandes Neto AJ, Prado RA. Comparative study on the abutment/implant fit of seven differents systems. J Dent Res 2001;80:1031-1031.

18. Silveira Júnior CD, Fernandes Neto AJ, Neves FD, Franco SD, Mendonça G. Laboratory procedures influence in the implant/UCLA abutment fit - pilot study. PCL 2002;4:392400 .

19. Kan JYK, Rungcharassaeng K, Bohsali K, Goodacre CJ, Lang BR. Clinical methods for evaluating implant framework fit. J Prosthet Dent 1999;81:7-13.

20. Brånemark $\mathrm{PI}$, Zarb GA, Albrektsson T. Introduction in Osseointegration. In: Osseointegration in clinical dentistry. Brånemark PI., Zarb GA, Albrektsson T (Editors). Chicago: Quintessence Books; 1985. 